ОЛЬГА СМОЛЬНИЦЬКА, кандидат фбілособбських наук (л. Kü̈в)

\title{
Архетипне дно вибраної лірики українських неокласиків
}

У статті пропонуеться спроба дослідити архетипне дно вибраних віршів украӥнських неокласиків. До уваги беруться бінарні опозииї, свідоле і несвідоле. Застосовується колпаративний аналіз. Дослідниия продовжує юнтіанський дискурс Ніли Зборовської. Стаття базована на здобутках літературознавства, міфбологічної школи, психоаналізу, gбілософбї.

Ключові слова: поезія, неокласицизл, архетип, ліфб, архетипне $\partial н о$.

Постановка проблеми в загальнолу вигляді та аналіз досліджень $i$ публікацій... Сучасний український неокласицизм плідно досліджуеться у вітчизняних і зарубіжних студіях - теоретично i практично. 3 публікацій варто назвати праці В. Агеєвої [1], О. Башкирової [2], О. Бросаліної, Н. Гаврилюк, О. Гальчук [3], «сьомого неокласика» I. Качуровського [9-11], Ю. Ковалева, В. Колесник, Л. Коломіець, Н. Костенко, Н. Котенко, В. Панченка, В. Погребенника, Г. Райбедюк, Г. Сивоконя, Л. Сірик [17], М. Стріхи [27-28], О. Смольницької [18-26], О. Томчука, М. Шаповал та ін. Постійна доповнюваність джерельної бази новими розвідками свідчить про інтерес учених до цього літературного явища. Стосовно практичного аспекту можна виокремити останнім часом перекладознавчий, педагогічний, мистецтвознавчий та ін., а також постійні культурні заходи (у тому числі організовувані Київським літературномеморіальним музеєм Максима Рильського). Також варто назвати поетів і перекладачів (більшість із них і науковці), які спираються на неокласичні засади: це імена О. Башкирової, Л. Вировець, Н. Гаврилюк, Н. Науменко, Олени О’Лір, О. Одріна, О. Смольницької, А. Содомори, М. Стріхи, Л. Хворост та ін. Тобто наявне гармонійне поєднання різних сфер діяльності, тип «ученого поета» (poeta docti). Але досі наявні недостатньо розроблені питання - зокрема, у плані архетипного і символогічного аналізу цих елітарних текстів. Так, перспективним виглядае юнгіанський метод. Слід висвітлити передумови його виникнення у сучасній українській науці. 
Український психоаналітик, літературознавець, літературний критик, письменниця Ніла Зборовська (1962-2011) в одній зі своїх пращь («Пихоаналіз і літературознавство») запропонувала застосувати юнгіанський аналіз (архетипну критику) до тексту - метод, яким сьогодні послуговуються у вітчизняній гуманітаристиці. У полі зору дослідниці була символістська драма О. Олеся «Осінь» (1913) з огляду на їі архетиповість. Схему твору Н. Зборовська назвала «архетипне дно драми» [6, с. 365]. Також допоміжним $є$ лесезнавчий аналіз Г. Левченко [12].

Форлулювання иілей статmі... Мета - вичленування паттернів несвідомого у вибраних віршах українських неокласиків. Поставлена мета передбачае завдання: 1) проаналізувати архетипне дно сонетів М. Рильського (раннього періоду), М. Зерова, М. Драй-Хмари; 2) дослідити античний вплив, взаємозв'язок із творами Лесі Українки, С. Маллярме (Малларме), М. Багдановіча та ін.; 3) простежити архетипне дно у нового поколінні неокласиків на прикладі віршів Олени О’Лір, присвячених ірландській тематиці. На перший план у дискурсі виступає сонет як канонічна форма, що передбачає мінімалізм лексичних засобів і граничну змістову насиченість. Фактично сонети неокласиків побудовані на архетипах різних культур, але ці складники інтерпретуються у різний спосіб.

Виклад основного матеріалу... У М. Рильського показова збірка «Під осінніми зорями» (1918) - вірш «Музика», присвячений «Пам'яті Іннокентія Анненського», де не так враження від музики Паганіні (що згадується як несподіваний хід у самому кінщі твору), скільки картина моторошної доби (1918 р. Рильських було вигнано з родового маєтку в селі Романівка, нинішня Житомирська область, і автентичний будинок було розграбовано та спалено) - революції та Громадянської війни. Фактично цей вірш - опис нічного жахіття: «Уночі налетіли вони - / Чорний вихор у чорному світі, / I заплакали дочки й сини, / Що батьки їх, батьки їх убиті» [16, с. 127]. Далі йдуть християнські алюзії: нова реальність не пожаліе немовлят (натяк на царя Ірода; немовлята - це молоде покоління, з яким незаслужено жорстоко повелися, а ще це й майбутні народжені діти - народжені вже в невільній країні, без власної держави), «на високім хресті розіпне» [16, с. 127]. Смерть постае як макабрична істота, ідол у королівськім вінщі, який «Самоцвітною кригою сяє» [16, с. 127] (вдало дібране слово "крига» показуе холодну сутність; чи не натяк це на Байронового Манфреда, описаного М. Рильським в іншому вірші, чи на модного тоді Ібсенового «Бранда»? може, образ Снігової Королеви?). Поет передбачив культ особи. Можна сказати, що цей текст - апокаліптична візія. Наліт - це і реальний 
напад, і чотири вершники Апокаліпсису. Смерть у вінці - і Антихрист, i вавилонська блудниця (докладніше: [24]).

У ліриці М. Рильського помітні такі архетипи: 1) архетипна пара: вершники («Уночі налетіли вони...»; закохані - Анімус і Аніма (абстрактна пара; літературні пари - Трістан та Ізольда, але Білорука, тобто фрактична дружина - невзаємне кохання; Беатріче - 3 натяком на Данте, тощо; 2) самітник (мисливець; Гамлет без Офелії, поет, самітник у келії чи у горах, порівняний з Манфредом, та ін.); 3) Анімус і Тінь (Гамлет - Полоній; герой убиває власну Тінь); 4) земля - амбівалентна: позитив як рідна земля, Батьківщина, цебто материнський код - i негативна (Тартар, пекло): вона народжуе, але і вбиває. Герой часто покидае кохану (абстрактну або конкретну: "I Ганнуся плаче, бо пора» [16, с. 254], «більше не прийду» [16, с. 117], «Трістан коня сідлає...», тощо) не з егоїзму, а бо йому суджено самотність як творчій постаті, звідси непроста Аніма: «I я чужий для тебе, і ти чужа мені» [16, с. 118]. Кохання може бути невзаємним, або ж Аніма - ілюзія. Лицар поклоняється Прекрасній Дамі та Мадонні, але не може лишитися 3 цією Анімою (недарма вона неземна, недоступна), бо його життя постійний шлях і постійний пошук. Фактично це і модель лицарських романів (можна згадати і мету - Ірааль, який автоматично закреслює можливість земних почуттів). Так само - поєднання іпостасей поета і воїна (недарма М. Рильський апелюе до образу Трістана). Прощання закоханої пари нагадуе споглядання реципіентом або згори, або здалеку. Але площини у цій ліриці можна розкласти на три світи (верх - середній - низ) чи дві бінарні опозиції (верх - низ, високе - низьке). Аніма у героя або літературна (Беатріче, Кармен, Афродіта - i iї іпостась Кіприда, та ін.), або земна, проте образ останньої не такий чіткий. Натомість Тінь виписана архетипово - але й сучасно. Це абстрактний ворог, незнайомець, але i конкретний опонент (вірш «Принц данський (Під хвилю зневіри)»), натяки на якого в сублімованих віршах могли прочитати підготовлені реципіенти. (Аналогічно - сонет М. Зерова «Incognito» про інформанта, сексота, приставленого до нього). Поступово Тінь формуеться з абстрактної до конкретної під час набування життям М. Рильського більшого трагізму. Фактично перелом у світогляді може бути з 1918 р., розгортання трагічної тематики - у 20-ті рр., до арешту в 1931 р. включно.

Кольорова символіка поетових віршів цього періоду - різноманітна, але на перший план виступають основні барви: червоний (багряний та інших відтінків), білий (срібний, сріблистий та ін.), чорний, золотий.

На окрему увагу заслуговуе образ тюльпана у М. Рильського. Це вірш «Миколі Зерову» (1926), який за життя не ввійшов до збірок. 
Фактично текст показуе принцип натхнення, який хвилював різні генерації вчених і студентів Київського університету ще від його бутності Імператорським університетом Святого Володимира: «Як тюльпан, що в Гаарлемі / Подорожньому киває / Крізь засніжене вікно - / Крізь імлу життя людського / Червоніє творчий задум / У поетовій душі» [16, с. 368]. Сніг - частий символ у ліриці М. Рильського. Цікавий вибір розміру романсеро - адже цей жанр асоціюеться не з Голландією, а $з$ Іспанією (якщо не брати до уваги завойовництво цією державою Нідерландів). Червоний колір як контраст білому (мертвотному) асоціюеться з полум'ям і кров'ю. Це квітка (тюльпан) і плід водночас. Фінал неоднозначний: «Низько ходить жовте сонце, / Сліпить очі вітер лютий, / Плачуть бідні ліхтарі, - / I самотньо розпускає / Пелюстки свої багряні / Довго пещений тюльпан» [16, с. 368-369]. У цьому вірші немає красивостей, тому сонце - «жовте», а не «золоте» чи інше, природа описується підкреслено невишуканим, «невисоким» стилем - як контраст до квітки у теплиці (а може, на підвіконні; у тексті спеціально не пояснюеться, чи квітку зрізано, чи вона росте у вазоні, а, значить, жива). Тюльпан самотній - це самотність митця. Сльота і сніг - життеві випробовування. Таким чином, цей вірш - про стійкість мистецтва. Дата написання якраз е підказкою, оскільки в 20-х рр. неокласики зазнали критиканства - зокрема, у київській газеті «Більшовик», де 3 продовженнями 1926 р. друкувалася стаття колишнього символіста Я. Савченка з нападами на «п'ятірне гроно».

Загалом тюльпан - вираження любові, кохання [30, с. 788]. Це виразно маскулінний символ (одне 3 тлумачень на Сході - воїн Аллаха). Але у християнських оповідях лілея i тюльпан мають відгомони лотосової традиції [30, с. 767], цебто містичної східної мудрості. Вважається, що тюльпан - аналог троянді на Заході й означає ідеальне кохання; у перській поезії ця квітка проросла з крові закоханих і тому червона [29] (те ж саме розповідають про троянду) звідси популярність цього символу в орієнтальній ліриці. За однією 3 версій, мова квітів прийшла в Свропу з Оттоманської імперії. Гаарлемський тюльпан згаданий М. Рильським недарма, оскільки згадану квітку завезли саме з Оттоманської імперії до Голландії, Гаарлем став одним із осередків «тюльпаноманії XVII ст., і сьогодні, як відомо, тюльпан - символ Нідерландів. (Ці фракти популярні у мистецтві й обіграні в дитячій повісті XIX ст. Мері Мейп Додж «Срібні ковзани» - українською переклала I. Стешенко). Мовою квітів тюльпан часто означає i форму без змісту, оскільки барвистий, але не має запаху; це швидкоплинна, минуча краса [29]. 
У М. Драй-Хмари його знаменитий сонет «Лебеді» (1928), де закодовано кредо «грона п'ятірного (аполлонізм), також виразно архетиповий. Цей сонет розкладається на дві бінарні опозиції - верх (небо, куди прямують лебеді) - i низ (темне несвідоме). Низ тут асоціюєтья з болотом. Вода як темне жіноче начало означає несвідоме, позначене як Танатос («небуття» [5, с. 102]). За власними словами, М. Драй-Хмара у своєму сонеті полемізував із сонетом С. Маллярме про лебедя (який переклав того ж року, 1928-го). Вірш С. Маллярме так і називаеться - «Сонет», в оригіналі дуже неоднозначний синтаксис (героєм може бути не лише лебідь, але й лід і навіть день). Якщо у французького символіста лебідь загинув на льоду, пішов у несвідоме (воду: адже крига - заморожена вода), то в українського неокласика оптимістично: «плавці ламали враз ті крижані лани, / і не страшні для них були зими погрози» [5, с. 102]. У С. Маллярме натомість - полеміка: «Краси пречистої безсмертний гордий син, / ударом п'яних крил чи ти розіб'єш нині / забуте озеро, де покриває іній / прозорий зльотів лід, що не дійшли вершин?» [5, с. 330]. Несвідоме=вода викликає асоціацію 3 іншим перекладеним неокласиками поетом - білоруським геніем М. Багдановічем (Богдановичем). Його перекладали неокласики різних поколінь: М. Драй-Хмара, І. Качуровський, Олена О’Лір, О. Смольницька. (Про неокласичну білорусистику: [17], [20]). У М. Багдановіча показовий «Сонет» про лілеї в болоті (для рими I. Качуровський відтворив їх «ненюфрарами» [9, с. 52]). Лілеї - це чиста краса, поезія, молодість, тендітність (мистецтво не витримуе зіткнення зі страшною реальністю, але ж водночас лілеї проростають у твані, цебто долають бруд). У вірші протиставлено білі лілеї (хоча колір не названий, але імпліцитно він мається на увазі) і брудна іржа болота, «мочарів». (Детальніше про символ лілеї в цьому контексті: [23]). Так само у сонеті «Лебеді» білизна цих птахів протиставлена імпліцитній чорноті страшної водної глибини, асоційованої з Тартаром, царством Аїда, а одночасно - 3 царством нестримного і грізного Посейдона. Водночас Посейдонове царство може сприйматись і позитивно - як «океан кипучого життя» [5, с. 102], тобто динаміка, а не статика. Також цей сонет інтертекстуальний: «крізь бурю й сніг гримить твій переможний спів» [5, с. 102], адже «Крізь бурю й сніг» - це книга М. Рильського (1925).

I, звичайно, у сонеті упадають у вічі античні символи - атрибути бога Аполлона. Це лебідь (птах жерців на містеріях, присвячених цьому богу), традиційно порівнюваний зі співцем, поетом; натяк на крилатий вислів «лебедина пісня» («лебединий спів») - адже, за давньогрецькими віруваннями, лебідь співає лише раз у житті, перед смертю; «сузір'я 
Ліри» [5, с. 102]: на лірі грав Аполлон. Отже, у сонеті тонко зашифровано поетичне кредо неокласиків, якому вони лишалися вірні. Прикметна дата написання сонета «Лебеді» - 1928 р. Це українізація, але й формування тоталітаризму, зокрема, колективізація, яку поети бачили на власні очі.

Сонетарій іншого неокласика - М. Зерова (якого називали «чистим неокласиком») уже докладно розглянутий попередніми дослідниками, тому варто просто виокремити провідні символи, образи і архетипи його поезії 20-х рр. Це як античні, так і вичитані 3 інших джерел наприклад, драми модного О. Вайлда «Саломея» («Salomé»). Так, у сонеті «Саломея», адресованому П. Филиповичу, прямо названо героя ціеї драми - Йоканаан [7, с. 9] (а не Йоанн чи Іоанн). Це підкреслюе, що автор мав на увазі саме вайлдівський твір, де пророка звуть Jokanaan, а не біблійний оригінал (де, до речі, відсутне ім'я Саломеї). М. Зеров міг читати цю трагедію як у перекладі К. Бальмонта (і навіть бачити на сцені), так і в оригіналі, оскільки володів англійською. Архетипи і символи цього сонета як біблійні, так і трансформовані модернізмом (О. Вайлдом), але М. Зеров пропонуе свою, третю, версію «Саломеї». Цебто цей вірш - інтерпретація інтерпретацій, шифр, розрахований на освіченого реципіента.

Якщо ж розгорнути античний ряд, то це один зі знаменитих сонетів - «Навсикая», побудований як діалог із М. Рильським (поетичний діалог - улюблена фрорма як «п'ятірного грона», так i сучасних неокласиків, або постнеокласиків) - недарма вірш відкрито словами 3 цього поета: «...ніжна Навсикая, / Струнка дочка Феацького царя» [7, с. 10]. Але у М. Зерова Навсикая - фрактично синонім калокагатії, бо для Одиссея царівна (яка невзаємно його покохала) - «радісна Краса» [7, с. 10]. Водночас поет не цураеться сатиричної лінії, згадуючи в одному вірші філософа і автора комедій (чий гумор сьогодні здається грубим): «Сократів бич / Чи невтишимий сміх Аристофана?» [8, с. 8]. Цікаве поєднання античності, біблійної та Дантової («Пекло») символіки - сонет 1921 р. »В царстві прообразів» (прообраз - це і $е$ архетип): у несвідомому (пеклі) провідником ліричного героя стає Вергілій. Звичайно, одразу виникає асоціація з Дантовим «Пеклом». Протиставленням темряві стають «ніжні лотоси і сніжнобілі лілії» [8, с. 14] (символіка лотоса і лілеї розглянута вище). Вони означають мудрість, чисту красу, також фемінінність (лілея - квітка Мадонни). Латинський "valle lacrimarum» [8, с. 14] означае "долина сліз». Це християнське позначення - земна юдоль, страждання, протиставлені небесам. Підсумок вірша - царство Петрарки. Вірш - про народження 
поезії з несвідомого. Данте і Петрарку можуть об’еднувати пограничний стан, уособлений у сублімуванні втрати Беатріче і Лаури.

Неокласики зверталися до античності, оскільки хаотичний час викликав бажання раціоналізувати дійсність. Звідси - інтерес до dpiлософрiї, риторики, калокагатії [26], агонів (що об’еднуе неокласиків 3 Лесею Українкою [25], яку вони по-справжньому й відкрили та своїми дослідженнями та виданнями запровадили до рідного їй європейського контексту). Водночас «п'ятірне гроно» ідеалізувало античність, пропонуючи їі як міфр просвіченого, як міфр гармонії, протиставленого варварському XX ст. Відповідно, Аполлон і Афродіта для неокласиків чиста краса, божественні натхненники, тоді як насправді культ цих божеств неодноразово трансформувався та містив навіть хтонічні риси й особливості, не відповідні сучасній естетиці ([4], [13-14]).

Але й сучасне покоління схильне до калокагії у рецепції аполлонізму. Так, Олена О’Лір прямо проголошуе у сонеті «Поет» свій принцип: «Собі небесну фрлейту заслужу / I буду посланцем при Аполлоні» [15, с. 22]. В архетиповій канві лірики поетеси помітно дві площини - верх і низ. Проте архетиповий верх тут або універсальний (узагалі небеса, божественне), або християнський, або пов'язаний 3 конкретними подіями чи творами («Дивовижна подорож Нільса 3 дикими гусьми» Сельми Лагерльоф, політ пілота - за фрільмом, тощо), або античний (Олімп, де Аполлон і музи). Високе у цій поезії розвинуто більше, тоді як низ - опосередкований (інфернальна почвара у «Видінні I» - «мана жорстока» [15, с. 65], абстрактна «вічна тьма» у сонеті «До ворога" [15, с. 30], та ін.). Також помітна кельтська модель світу: пошуки Ультіма Туле в океані (плавба - вірш «Пісня невідомого мореплавця (Друге відкриття Туле)» [15, с. 72], чарівна країна - у тому числі сідів та інших героїв ірландських скел (саг), - тобто рух уперед, але лінійний. Як відомо, у кельтів було два уявлення про потойбічний світ - це або Країна Вічної Молодості (Тip-на-Ног - «острів юних»), за морями, або Край під Пагорбами (Сід - ірл. Sidhe), чиїх мешканщів сідів (сучасн. ши) та інших колишніх язичницьких богів - евфемістично називали «Народ під Пагорбами». Підземний світ у кельтській міфрології та фольклорі (аналогічно - у скандинавській) надзвичайно яскраво виписаний. Але помітно, що модель кельтської міфології переважно лінійна. 3 персонажів авторку цікавлять передовсім яскраві, але не макабричні, а більш-менш гармонійні та героїчні, проте не статичні (Муйрхертах, Сін та ін.). Якщо М. Зеров перелічує античних героїв і фрілософрів, а також географічні назви вичитаних джерел, розраховуючи у діалозі на підготованого співбесідника, то Олена О’Лір застосовуе цей спосіб у переліку імен з «Ірландських саг» (у 
російському перекладі О. Смирнова, видавництво Academia, у 30-ті pp. репресоване), надихнена покажчиком із ціеї книги, де «Є Фахтна, ліка, а його сусіди - / Прекрасна Фанд і Файльбе Світлий, сіди / 3 тих островів, що Бран колись досяг. / Тут Мананнан, який по хвилях їде...» [15, с. 25] (вірш «Сонет»). Якщо М. Зеров - античник і універсальний фрахівець 3 української та інших літератур, то Олена О’Лір ірландистка, англістка, знавчиня української словесності.

Таким чином, здійснений аналіз виявив спільні засади у віршах неокласиків різних генерацій. Це аполлонізм (часто прямо декларований), увага до канонічної форми, націєтворча мета поезії, прагнення ratio y хаосі. Архетипне дно виступае цікавим i різноманітним - від античних до біблійних і власне українських архетипів; помітне розкриття міфологічних паттернів інших культур (кельтської в Олени О’Лір). Вичленовуються бінарні опозиції: верх/низ, високе/низьке, свідоме/несвідоме, дух/матерія. Але водночас матерія стає духом, переосмислюючись і очищуючись у поезії. Робота має перспективу продовження 3 огляду на потребу глибше розкрити науковий метод Н. Зборовської, уперше застосований до неокласичних текстів.

\section{Список використаних джерел і літератури:}

1. Агеєва В. Мистецтво рівноваги. Максим Рильський на тлі епохи. Київ: Книга, 2012. 392 с.

2. Башкирова О. Невигадана Ірландія Олени О’Лір. Слово i час. 2007. №9. C. 57-64.

3. Гальчук О.В. »...Не минае міт!» : Античний текст у поетичному просторі українського модернізму 1920-1930-х років: [монографія]. Чернівці: Книги - XXI, 2013. 552 с.

4. Грейвс Р. Мифы Древней Греции. Екатеринбург: У-Фактория, 2005. $1008 \mathrm{c}$.

5. Драй-Хмара М. Вибране. Упоряд. Д. Паламарчука, Г. Кочура; Передм. І. Дзюби. Київ: Дніпро, 1989. 542 с.

6. Зборовська Н. В. Психоаналіз і літературознавство: посіб. Київ: Академвидав, 2003. 392 с.

7. Зеров М. Камена. Київ: Час, 1990. 80 с.

8. Зеров М. Сонети і елегії. Київ: Час, 1990. 80 с.

9. Качуровський I. Круг понадземний: Світова поезія від VI по XX століття: Переклади / пер., післям. І. Качуровського. Київ: Вид. дім «КиевоМогилянська академія», 2007. 527 с.

10. Качуровський I. Оце твоя, поезіе, дорога! Україна модерна. 2008. Ч. 13(2). Київ: Критика, 2008. С. 209.

11. Качуровський I. Український парнасизм. Визвольний шлях. 1983. Квітень. Кн. 4. С. 472-483. 
12. Левченко Г. Мір проти історії: Семіосфера лірики Лесі Українки: [монографія]. Київ: Академвидав, 2013. 332 с.

13. Лосев А. Ф. Аполлон. Мифбь народов мира. Энциклопедия: в 2-х mm. / Гл. ред. Токарев С. А. 2-е изд. Т. 1. А-К. Москва: Сов. энциклопедия, 1991. С. 9 95.

14. Лосев А. Ф. Адрродита. Там же. С. 132-133, 135.

15. О’Лір О. Прочанські пісні: Поезії і переклади. Київ: Вид. дім «КиевоМогилянська академія», 2006. 143 с.

16. Рильський М. Зібрання творів: У 20-ти тт. Т. 1. Поезії 1907-1929. Проза 1911-1925. Київ: Наук. думка, 1983. 535 с.

17. Сірик Л. Прагнення Свропи: Творчість київських неокласиків. Lublin: Wydawnictwo Uniwersitetu Marii Curie-Skłodowskiej, 2013. 380 c.

18. Смольницька О. Античні паралелі у поезії Максима Рильського, Миколи Зерова і Леконта де Ліля: компаративний і перекладознавчий аналіз. Сучасні проблели мовознавства і літературознавства: зб. наук. праць / відп. ред. І. В. Сабадош. Ужгород, 2018. Вип. 23. С. 299-304.

19. Смольницька О. О. Аполлонізм у ранній ліриці Максима Рильського і поетичній збірці Віри Вовк «Чорні акації». Сучасна фбілологія: актуальні наукові проблеми та шляхи вирішення: Міжнародна науково-практична конференція, м. Одеса, 27-28 квітня 2018 року. Одеса: Південноукраїнська організація «Центр філологічних досліджень», 2018. Ч. 1. С. 24-28.

20. Смольницька О. Білоруські поети XX ст. у перекладах українських неокласиків. Науковий часопис Національного педагогічного університету ілені М. П. Драгоманова. Серія 8. Філологічні науки (мовознавство $i$ літературознавство): [збірник наукових статей] / $M$-во освіти $i$ науки України, Наи. пед. ун-т ілені М. П. Драголанова. / Biдn. ред. В. Ф. Погребенник. Київ: Вид-во НПУ імені М. П. Драгоманова, 2018. Вип. 10. С. 59-65.

21. Смольницька О. Відображення картини світу в поемі Лесі Українки «Ізольда Білорука» та поезії М. Рильського: аналіз архетипів. Наш украӥнський di.n. 2018. №1. Ніжин, 2018. С. 48-51.

22. Смольницька О.О. Діонісійство у перекладах французької поезії Максимом Рильським: противага аполлонізму чи доповнення. Перспективи розвитку ббілологічних наук. Матеріали IV Міжнародної науково-практичної конферениії (м. Вінниия, 9-10 лютого 2018 року). Херсон: Вид-во «Молодий вчений», 2018. С. 49-53.

23. Смольницька О. О. Символ лілеї у поезії білоруських неокласиків на прикладі Максима Богдановича: релігійний підтекст у порівнянні 3 латиноамериканським дискурсом і творчістю Віри Вовк. Мова $і$ культура. (Науковий журнал). Філологічні читання пал'яті М. М. Гіршлана : Матеріали Всеукраїнської наукової конфберениії (19-20 жовтня 2017 р.). Київ: Вид. дім Дмитра Бураго, 2018. Вип. 21. Т. III (192). С. 92-99.

24. Смольницька О. О. Спільні засади ранньої лірики Максима Рильського, Анни Ахматової та Володимира Шилейка: контекстуальний аналіз. The 6th International conference - "Science and society" (August 3, 2018). Accent Graphics Communications \& Publishing, Hamilton, Canada. 2018. P. 11-23. 
25. Смольницька О. О. Філософські проблеми літературознавства ХIX ст. в контексті досліджень М. Зерова. Дні науки фбілософбського фбакультету - 2010: Міжнародна наукова конфберенція (21-22 квітня 2010 року): Матеріали доповідей ma виступів. Київ: Видавничо-поліграфічний центр «Кийвський університет», 2010. Ч. II. С. 38-39.

26. Смольницька О.О. Філософсько-методологічні засади літературознавчих досліджень в Київському університеті кінця XIX - початку XX ст.: [монографія]. К., 2013. 208 с.

27. Стріха М. Неокласична проща Олени О’Лір. О’Лір О. Прочанські пісні : Поезї̈ і переклади. К.: Вид. дім «Киево-Могилянська академія», 2006. С. 6-10.

28. Стріха М. Український художній переклад: між літературою i націетворенням. Київ: Факт - Наш час, 2006. 344 с.

29. Тюльпан. URL: http://sigils.ru/signs/tulpan.html (дата обращения 26.02.2017).

30. Энциклопедия символов / сост. В. М. Рошаль. Москва: АСТ; СПб.: Сова, 2008. 1007, [1] с.: ил.

\section{References:}

1. Aheyeva V. Mystetstvo rivnovahy. Maksym Ryl's'kyy na tli epokhy. K.: Knyha, 2012. $392 \mathrm{~s}$.

2. Bashkyrova O. Nevyhadana Irlandiya Oleny O»Lir. Slovo i chas. 2007. \#9. S. 57-64.

3. Hal'chuk O. V. «...Ne mynaye mit!»: Antychnyy tekst u poetychnomu prostori ukrayins'koho modernizmu 1920-1930-kh rokiv: Monohrafiya. Chernivtsi: Knyhy - XX, 2013. $552 \mathrm{~s}$.

4. Grejvs R. Mify Drevnej Grecii. Ekaterinburg: U-Faktorija, 2005. 1008 s.

5. Dray-Khmara M. Vybrane. Uporyad. D. Palamarchuka, H. Kochura; Peredm. I. Dzyuby. K.: Dnipro, 1989. $542 \mathrm{~s}$.

6. Zborovs'ka N. V. Psykhoanaliz i literaturoznavstvo: Posibnyk. K.: Akademvydav, 2003. $392 \mathrm{~s}$.

7. Zerov M. Kamena. K.: Chas, 1990. $80 \mathrm{~s}$.

8. Zerov M. Sonety i elehiyi. K.: Chas, 1990. $80 \mathrm{~s}$.

9. Kachurovs'kyy I. Kruh ponadzemnyy: Svitova poeziya vid VI po XX stolittya: Pereklady. Per., pislyam. I. Kachurovs'koho. K.: Vyd. dim «KyyevoMohylyans'ka akademiya», 2007. $527 \mathrm{~s}$.

10. Kachurovs'kyy I. Otse tvoya, poeziye, doroha! Ukrayina moderna. 2008. Ch. 13(2). K.: Krytyka, 2008. S. 209.

11. Kachurovs'kyy I. Ukrayins'kyy parnasyzm. Vyzvol'nyy shlyakh. 1983. Kviten'. Kn. 4. S. 472-483.

12. Levchenko H. Mif proty istoriyi: Semiosfera liryky Lesi Ukrayinky: monohrafiya. K.: Akademvydav, 2013. 332 s.

13. Losev A. F. Apollon. Mify narodov mira. Jenciklopedija: $v$ 2-h tt. I Gl. red. Tokarev S. A. 2-e izd. T. 1. A-K. M.: Sov. jenciklopedija, 1991. S. 92-95.

14. Losev A. F. Afrodita. Tam zhe. S. 132-133, 135.

15. O»Lir O. Prochans'ki pisni: Poeziyi i pereklady. K.: Vyd. dim «KyyevoMohylyans'ka akademiya», 2006. $143 \mathrm{~s}$. 
16. Ryl's'kyy M. Zibrannya tvoriv: U 20-ty tt. T. 1. Poeziyi 1907-1929. Proza 1911-1925. K.: Nauk. dumka, 1983. 535 s.

17. Siryk L. Prahnennya Yevropy: Tvorchist' kyyivs'kykh neoklasykiv. Lublin: Wydawnictwo Uniwersitetu Marii Curie-Skłodowskiej, 2013. $380 \mathrm{~s}$.

18. Smol'nyts'ka O. Antychni paraleli u poeziyi Maksyma Ryl's'koho, Mykoly Zerova i Lekonta de Lilya: komparatyvnyy i perekladoznavchyy analiz. Suchasni problemy movoznavstva $i$ literaturoznavstva (zbirnyk naukovykh prats') I vidp. red. I. V. Sabadosh. Uzhhorod, 2018. Vyp. 23. S. 299-304.

19. Smol'nyts'ka O. O. Apollonizm u ranniy lirytsi Maksyma Ryl's'koho i poetychniy zbirtsi Viry Vovk «Chorni akatsiyi». Suchasna filolohiya: aktual'ni naukovi problemy ta shlyakhy vyrishennya: Mizhnarodna naukovo-praktychna konferentsiya, m. Odesa, 27-28 kvitnya 2018 roku. Odesa: Pivdennoukrayins'ka orhanizatsiya «Tsentr filolohichnykh doslidzhen'«, 2018. Ch. 1. S. 24-28.

20. Smol'nyts'ka O. Bilorus'ki poety XX st. u perekladakh ukrayins'kykh neoklasykiv. Naukovyy chasopys Natsional'noho pedahohichnoho universytetu imeni M. P. Drahomanova. Seriya 8. Filolohichni nauky (movoznavstvo $i$ literaturoznavstvo): [zbirnyk naukovykh statey] / M-vo osvity i nauky Ukrayiny, Nats. ped. un-t imeni M. P. Drahomanova. / Vidp. red. V. F. Pohrebennyk. K.: Vydvo NPU imeni M. P. Drahomanova, 2018. Vyp. 10. S. 59-65.

21. Smol'nyts'ka O. Vidobrazhennya kartyny svitu v poemi Lesi Ukrayinky «Izol'da Biloruka» ta poeziyi M. Ryl's'koho: analiz arkhetypiv. Nash ukrayins'kyy dim. 2018. \#1. Nizhyn, 2018. S. 48-51.

22. Smol'nyts'ka O. O. Dionisiystvo u perekladakh frantsuz'koyi poeziyi Maksymom Ryl's'kym: protyvaha apollonizmu chy dopovnennya. Perspektyvy rozvytku filolohichnykh nauk. Materialy IV Mizhnarodnoyi naukovo-praktychnoyi konferentsiyi (m. Vinnytsya, 9-10 lyutoho 2018 roku). Kherson: Vyd-vo «Molodyy vchenyy», 2018. S. 49-53.

23. Smol'nyts'ka O. O. Symvol lileyi u poeziyi bilorus'kykh neoklasykiv na prykladi Maksyma Bohdanovycha: relihiynyy pidtekst $u$ porivnyanni $\mathrm{z}$ latynoamerykans'kym dyskursom i tvorchistyu Viry Vovk. Mova i kul'tura. (Naukovyy zhurnal). Filolohichni chytannya pamıyati M. M. Hirshmana : Materialy Vseukrayins'koyi naukovoyi konferentsiyi (19-20 zhovtnya 2017 r.). K.: Vyd. dim Dmytra Buraho, 2018. Vyp. 21. T. III (192). S. 92-99.

24. Smol'nyts'ka O. O. Spil'ni zasady rann'oyi liryky Maksyma Ryl's'koho, Anny Akhmatovoyi ta Volodymyra Shyleyka: kontekstual'nyy analiz. The 6th International conference - "Science and society" (August 3, 2018). Accent Graphics Communications \& Publishing, Hamilton, Canada. 2018. P. 11-23.

25. Smol'nyts'ka O. O. Filosofs'ki problemy literaturoznavstva XIX st. v konteksti doslidzhen' M. Zerova. Dni nauky filosofs'koho fakul'tetu - 2010: Mizhnarodna naukova konferentsiya (21-22 kvitnya 2010 roku): Materialy dopovidey ta vystupiv. K.: Vydavnycho-polihrafichnyy tsentr «Kyyivs'kyy universytet», 2010. Ch. II. S. 38-39.

26. Smol'nyts'ka O. O. Filosofs'ko-metodolohichni zasady literaturoznavchykh doslidzhen' $\mathrm{v}$ Kyyivs'komu universyteti kintsya XIX - pochatku XX st.: Monohrafiya. K., 2013. $208 \mathrm{~s}$. 
27. Strikha M. Neoklasychna proshcha Oleny O»Lir. O»Lir O. Prochans'ki pisni : Poeziyi i pereklady. K.: Vyd. dim «Kyyevo-Mohylyans'ka akademiya», 2006. S. 6-10.

28. Strikha M. Ukrayins'kyy khudozhniy pereklad: mizh literaturoyu i natsiyetvorennyam. K.: Fakt - Nash chas, 2006. 344 s.

29. Tjul'pan. URL: http://sigils.ru/signs/tulpan.html (Accessed: 26.02.2017).

30. Jenciklopedija simvolov / sost. V. M. Roshal'. M.: ACT; SPb.: Sova, 2008. 1007, [1] s.: il.

\section{Summary \\ Olga Smolnytska \\ The Archetypal Bottom of the Selected Lyrics of the Ukrainian Neoclassicists}

The article proposes an attempt to explore the archetypal bottom of the selected poems of the Ukrainian neoclassicists. Attention is drawn to the binary oppositions, the spheres of conscious and unconscious. A comparative analysis is used. The research proves that there is a link between the specific poems of the Ukrainian neoclassicists and the works of other literatures (as the French or Belorussian ones) translated by these poets. There are also patterns with the works of Lessya Ukrainka who was discovered and comprehensively analyzed by the neoclassicists in her European context. The study analyses the patterns, archetypes and symbols of the Antique (Greek and Roman), Celtic (Irish) and other mythologies which are in the neoclassical texts. The "clear" cults of Apollo and Aphrodite as symbols of the Ukrainian neoclassicists are researched in their evolution. The article analyses the neoclassicists of different generations. The researcher continues the Jungian discourse of Nila Zborovska offered by this Ukrainian psychoanalyst, literature critic and writer. The article is based on the achievements of literary studies, mythological school, psychoanalysis, philosophy. The research has a theoretical and practical orientation.

Key words: poetry, neoclassicism, archetype, myth, archetypical bottom.

Дата надходження статті: «13» вересня 2018 р.

Дата прийняття до друку: «27» вересня 2018 р. 